\title{
PERAN KEPALA SEKOLAH DAN PENGAWAS SEBAGAI SUPERVISOR PENDIDIKAN UNTUK MENINGKATKAN MUTU PENDIDIKAN
}

\author{
Neva Vioretha \\ Email: nevavioretha211098@gmail.com
}

ABSTRAK

Peranan Kepala Sekolah dalam mengelola sekolah terutama dalam mutu dan kualitas pendidikan merupakan hal yang sangat penting. Kepala sekolah dan pengawas merupakan penggerak dalam meningkatkan sumber daya sekolah terutama pendidik dan peserta didik. Kepala sekolah dan pengawas bertanggung jawab untuk membina dan mengawasi jalannya proses pedidikan. Pendidik atau guru di bombing dalam kegiiatan supervise pendidikan. Kepala sekolah sebagai supervisor mengadakan kunjungan kelas pada saat guru mengajar di kelas. Sehingga proses pendidikan berlangsung kondusif dan efektif, serta menghasilkan peserta didik yang bermutu dan berkualitas.

Kata Kunci : supervise pendidikan, mutu pendidikan, dan supervisor

\section{LATAR BELAKANG}

Salah satu permasalah suatu instansi pendidikan adalah, mutu pendidikan. Mutu pendidikan yang rendah disebabkan tujuh faktor, yaitu; pembelajaran hanya berpatokan pada buku paket, mengajar satu arah (ceramah satu arah), kurangnya sarana belajar terutama di daerah, aturan yang mengikat, budaya mencontek, metode pertanyaan terbuka tak dipakai, dan guru tak menanamkan diskusi dua arah.

Kualitas pendidikan di Indonesia saat ini sangat memprihatinkan. Dikutip dari (cnn, 2018) yaitu dibuktikan dengan data UNESCO (2000) tentang peringkat Indeks Pengembangan Manusia (Human Development Index), yaitu komposisi dari peringkat pencapaian pendidikan, kesehatan, dan penghasilan per kepala. Faktanya, indeks pengembangan manusia Indonesia makin menurun. Di antara 174 negara di dunia, Indonesia menempati urutan ke-102 (1996), ke99 (1997), ke-105 (1998), dan ke-109 (1999).

Untuk mengatasi hal tersebut, pendidikan di Indonesia harusnya melakukan supervisi pendidikan. Supervise dilakukan oleh supervisor yaitu kepala sekolah dan pengawas sekolah. supervise dilakukan agar kita dapat mengetahui kekurangan yang ada dan mencari solusi agar pendidikan kedepannya dapat berjalan dengan baik. Namun ternyata dari berbagai hasil penelitian, pengamatan dan pengalaman, supervisi pendidikan belum mencapai tujuan tersebut. Hal ini terjadi karena jarangnya pengawas maupun kepala sekolah dalam melakukan supervise.

Menurut sabandi (Sabandi, 2013a) Supervisor memegang peranan penting dalam meningkatkan kualitas guru agar dapat melaksanakan pembelajaran yang lebih berkualitas. Jabatan supervisor di sekolah meliputi kepala sekolah dan pengawas. Supervisi yang dilakukan oleh kepala sekolah diatur dalam Permen Diknas Nomor 13 Tahun 2007 tentang Standar Kepala Sekolah/Madrasah. 
Sedangkan Kepala sekolah sebagai pimpinan tertinggi di lembaganya, dituntut untuk memiliki kemampuan (ability) serta kompetensi yang berkaitan dengan tugasnya. Salah satunya adalah menyusun program supervisi akademik (Astarini, n.d.)

Berdasarkan uraian di atas maka permasalahan dalam tulisan ini adalah (1) Bagaimana pelaksanaan supervisi pendidikan di Indoensia, (2) Bagaimana cara meningkatkan serta mengefektifkan supervisi pendidikan di Indonesia? (3) Bagaimana peran supervisor pendidikan di Indonesia. Tujuan tulisan ini adalah (1) untuk mengetahui bagaimana pelaksanaan supervisi pendidikan di Indoensia, (2) untuk mengetahui bagaimana cara meningkatkan serta mengefektifkan supervisi pendidikan di Indonesia dan (3) untuk mengetahui bagaimana peran supervisor pendidikan di Indonesia.

\section{PEMBAHASAN}

Penyebab rendahnya mutu pendidikan di Indonesia antara lain adalah masalah efektivitas, efisiensi dan standarisasi pengajaran. Kurang kreatifnya para pendidik dalam membimbing siswa membuat siswa dan lulusan sekolah menjadi kurang bermutu. Selain itu kurikulum hanya didasarkan pada pengetahuan pemerintah tanpa memperhatikan kebutuhan masyarakat.sehingga pendidikan tidak mampu menghasilkan lulusan yang kreatif . Selain itu kurikulum dibuat di pusat tanpa memperhatikan kondisi di masyarakat bawah atau di daerah sampai daerah terpencil, sehingga seringkali kurikulum yang dibuat susah untuk diterapkan di beberapa sekolah maupun daerah.

Oleh karena itu, diperlukan supervisi sebagai cara dalam peningkatan kualitas atau mutu pendidikan di Indonesia. Namun sayangnya, supervisi sering tidak berjalan lancar oleh pihak yang berkewajiban. Hal tersebut dapat berupa factor internal maupun eksternal. Beberapa factor yang mempengaruhi supervise pendidikan ini adalah Sumber daya guru, SDM pimpinan lembaga pendidikan, SDM tenaga administrasi, Anak didik itu sendiri, struktur organisasi pengawas serta pola pengawasan yang diterapkan.

Menurut (Sabandi, 2013b) Perkembangan supervisi pendidikan berkembang seiring dengan perkembangan ilmu pengetahuan, teknologi, serta sosial ekonomi dan budaya masyarakat. Oleh karena itu, pendidik diharapkan mampu mengayomi peserta didik seiring dengan perkembangan IPTEK, ekonomi dan budaya masyaratakat yang sesuai dengan keaadaan saat itu juga. Dan kepala sekolah serta badan pengawas sekolah diharapkan mampu memberikan pelatihan kepada pendidik sehingga pendidik mampu mengajar dan menghasilkan siswa yang berkualitas dan berkemajuan.

Peningkatan kemampuan guru dalam melaksanakan proses belajar mengajar, perlu secara terus menerus mendapatkan perhatian dari penanggung jawab sistem pendidikan. Supervisor sebagai penanggung jawab keberhasilan penyelenggaraan pendidikan dapat melakukan supervisi dengan berbagai pendekatan untuk meningkatkan mutu pendidikan dan keprofesionalitasan guru, di antaranya teknik supervisi, budaya organisasi pembelajaran, dan kegiatan pelatihan. Agar dapat melaksanakan supervisi dengan efektif, pengawas harus memahami prinsip-prinsip dalam melaksanakan supervisi. Dikutip dari buku pedoman pelaksanaan supervisi yang diterbitkan oleh Ditjend Dikdasmen (1994) disebutkan bahwa ada empat prinsip dalam melaksanakan supervisi, yaitu: (1) ilmiah (scientific); (2) demokrasi; (3) Kooperatif; (4) Konstruktif dan Kreatif. Selain 
itu kepala sekolah memiliki peranan penting dalam supervisi ini sebagai pembina yang memberikan arahan, bimbingan, contoh dalam proses pembelajaran di sekolah.

\section{PENUTUP}

\section{Kesimpulan}

Berdasarkan penjelasan diatas, disimpulkan bahwa masih kurangnya pelaksanaan supervise pendidikan. Supervise pendidikan dapat diartikan sebagai suatu penjamin dan pengontrol mutu pendidikan agar tidak lari dari acuan dan dapat mencapai hasil dari tujuan pendidikan. Agar tujuan tersebut tercapai maka diperlukan suatu upaya dalam pengawasan saat berlangsungnya proses pendidikan. Oleh karena salah satu yang menjadi pusat perhatian adalah kualitas yang dimiliki oleh seorang pendidik. Maka dari itu seorang supervisor, baik itu kepala sekolah maupun pengawas pendidikan berkewajiban untuk menilai, memperhatikan kelemahan yang ada, melakukan sebuah pembinaan, dan kemudian melakukan perbaikan. Barulah mutu dari pendidikan dapat terkontrol sehingga pendidikan berkualitas.

\section{Saran}

Dalam upaya meningkatkan mutu atau kualitas pendidikan di Indonesia, maka sekolah dan pengawas yang bertindak sebagi supervisor agar dapat mengontrol pendidik agar memiliki kualitas mengajar yang baik, sehingga siswa kelak dapat menjadi lulusan yang baik, kreatif dan berkualitas.

\section{Referensi}

Astarini, D. (n.d.). MENINGKATKAN KEMAMPUAN KEPALA SEKOLAH DALAM MENYUSUN PROGRAM SUPERVISI AKADEMIK MELALUI PENDAMPINGAN DAN SUPERVISI MANAJERIAL. Jurnal Ilmiah Ilmu Pendidikan, 36-41. Retrieved from http://journal2.um.ac.id/index.php/jmsp/article/download/1854/1086

cnn, indonesia. (2018). Ada Apa dengan Pendidikan di Indonesia. Retrieved from https://student.cnnindonesia.com/edukasi/20180103112420-445-266335/ada-apa-denganpendidikan-di-indonesia/

Sabandi, A. (2013a). SUPERVISI PENDIDIKAN UNTUK PENGEMBANGAN PROFESIONALITAS GURU BERKELANJUTAN. Pedagogi, Jurnal Ilmiah Ilmu Pendidikan, XIII(2), 1-9. $\quad$ Retrieved from http://ejournal.unp.ac.id/index.php/pedagogi/article/view/4275 